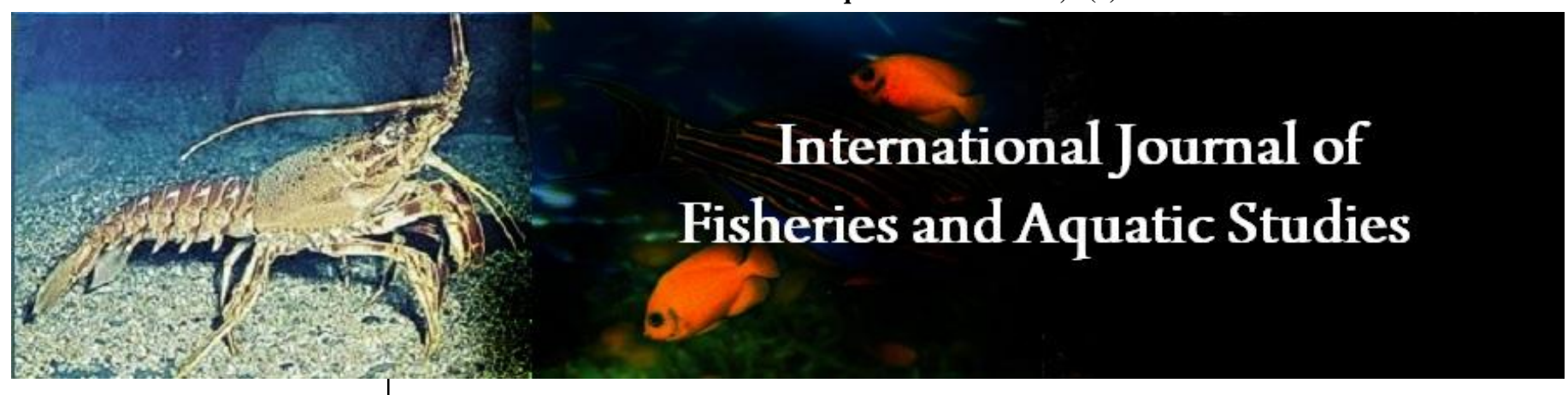

E-ISSN: 2347-5129

P-ISSN: 2394-0506

(ICV-Poland) Impact Value: 5.62

(GIF) Impact Factor: 0.549

IJFAS 2020; 8(6): 84-87

(C) 2020 IJFAS

www.fisheriesjournal.com

Received: 03-09-2020

Accepted: 09-10-2020

Pinandoyo

Department of Aquaculture,

Diponegoro University

Semarang, Central Java,

Indonesia

\section{Dicky Harwanto}

Department of Aquaculture,

Diponegoro University

Semarang, Central Java,

Indonesia

\section{Seto Windarto}

Department of Aquaculture,

Diponegoro University

Semarang, Central Java,

Indonesia

Vivi Endar Herawati Department of Aquaculture,

Diponegoro University

Semarang, Central Java,

Indonesia
Corresponding Author:

Pinandoyo

Department of Aquaculture,

Diponegoro University

Semarang, Central Java,

Indonesia

\section{The effects of addition Tyroxin hormone on growth and the survival rate of giant prawn Macrobrachium rosenbergii}

\author{
Pinandoyo, Dicky Harwanto, Seto Windarto and Vivi Endar Herawati
}

\author{
DOI: https://doi.org/10.22271/fish.2020.v8.i6b.2363
}

\begin{abstract}
Giant prawn is one of the consumption fish that is in demand by the public, as well as in the international market. To properly cultivate giant prawns, growth factors related to the quality and nutrition of feed must be considered. The purpose of this study was to determine the effect of the addition of thyroxin hormone in artificial feed on the growth and survival of giant prawns (Macrobrachium rosenbergii). The cultivation container used was an aquarium measuring $60 \times 40 \times 30 \mathrm{~cm}^{3}$, as many as 12 tanks. Prawn used were giant prawns measuring $1 \mathrm{~g} /$ individual, with density was 20 individuals / $20 \mathrm{~L}$ of water. Water quality control was done by siphoning off the remaining feed and feces, and also water media was changing as much as $20 \%$ a day. The feed given was $5 \%$ of biomass/day weight with a frequency of 3 times a day. The experimental design used was a completely randomized design with four treatments and three replications, Treatment A (thyroxin hormone $0 \mathrm{mg} / \mathrm{kg}$ feed), B (thyroxin hormone $5 \mathrm{mg} / \mathrm{kg}$ feed), $\mathrm{C}$ (thyroxin hormone $10 \mathrm{mg} / \mathrm{kg}$ feed), D (thyroxin hormone $15 \mathrm{mg} / \mathrm{kg}$ of feed). Data taken include daily growth rate, survival, absolute growth, feed conversion, protein retention, protein efficiency, digestibility and water quality. Analysis of growth data and efficiency of feed utilization using variance analysis (ANOVA). The research activity was carried out in August - October 2015 at the Center for Freshwater Cultivation (BBBAP) Jepara, Central Java. From the results of statistical tests, it can be seen that the addition of thyroxine hormone to growth and survival gives a significant influence. The results showed that the absolute growth rates of treatments A, B, C, and D were 5.66; 7.62; 10,12; and 9.29 g, respectively, specific growth rate (SGR) were 0.484 ; B 0,636; 0.770; 0,762\% / day, respectively, while the survival rate were $75 ; 78 ; 88$; And $83 \%$, respectively.
\end{abstract}

Keywords: Giant prawn, feed, thyroxin hormone, growth, and survival rate

\section{Introduction}

The giant freshwater (or river) prawn Macrobrachium rosenbergii (de Man, 1879) is native to the tropical and subtropical Indo-West Pacific region, extending eastwards from India to Southeast Asia and Papua New Guinea (De Grave et al, 2013) ${ }^{[4]}$. Giant prawns are one type of freshwater prawn that many people are interested in consuming. This can be seen from the trend of increasing prices of giant prawns on the international market. Giant prawns are easy to maintain and resistant to disease. Its body size and taste of meat are similar to baby lobster. That's what makes giant prawn have the prospect of being exported. One of the factors that influence prawn farming is the feed factor. Prawn has less optimal utilization of feed. One of the factors controlling the efficiency of feed utilization is hormonal factors, namely the thyroxine hormone. Thyroxine functions in increasing growth and metabolism by regulating the speed of oxidation in cells. The thyroxine hormone released by the thyroid gland with stimulation from the pituitary gland, which secures thyrotropin, serves to help regulate development, growth, metabolism, and reproduction. Thyroid hormones have a broad range of function, but are best known for their effects on development and metabolism (Little and Frank, 2014) ${ }^{[9]}$.

This study used the thyroxine hormone which is expected to have a direct effect on the efficiency of feed utilization and indirectly have an effect on the efficiency of the use of protein so that it will increase growth and suppress prawn mortality. The growth that occurs is influenced by nutritional needs, one of which is protein requirements. Good efficiency in feed utilization is expected to have an effect on good efficiency in the utilization of the protein too. Also, this is expected to be able to increase the nutritional needs of the complete essential 
amino acids in the protein, so that it can influence the increase in the rate of growth and survival.

\section{Materials and Methods \\ 2.1 Materials}

2.1.1 Prawns

The test prawns used were fingerling giant prawns (Macrobrachium rosenbergii de Man). Stocking density was 20 fish / $20 \mathrm{~L}$ of water, with a weight ranging from 1-2 g. The research activity was conducted at the Freshwater Cultivation Center (BBAT) Sukabumi, West Java.

\subsubsection{Feed}

The test feed used was artificial feed in the form of crumble. The feed was given 4 different doses of thyroxine hormone treatment, namely A (0 mg / kg feed), B (5 mg / kg feed), C (10 $\mathrm{mg} / \mathrm{kg}$ feed), and D (15 mg / kg feed). This is based on Matty (1985) ${ }^{[10]}$, who stated that the administration of thyroxine hormone at a dose of $10 \mathrm{mg} / \mathrm{kg}$ of feed into artificial feed could increase growth. Also Murtidjo (1992) ${ }^{[11]}$ which states that for the early giant prawn stage, about $40 \%$ of protein is needed in the feed. The frequency of feeding is three times a day. The amount of food given was 5\% biomass/day (Khairuman and Amri, 2004) ${ }^{[8]}$. The composition of feed ingredients was presented in Table.1.

\subsubsection{Hormone}

The thyroxine hormone used in this study is the thyroxine hormone synthesis with the trademark "Thyrax", which contains $0.1 \mathrm{mg}$ thyroxine (L-3,5,3 ', 5' - tetraiodothyronine) or T4. Every single tablet $0.1 \mathrm{mg}$ thyroxine contains sodium thyroxine.

\subsubsection{Culture tank and water media}

The culture tank was an aquarium measuring $60 \times 40 \times 30 \mathrm{~m}^{3}$, 12 tanks, with a volume of $20 \mathrm{~L}$ water each. The aquarium was equipped with aeration and heater. Each aquarium contains 20 fingerling giant prawns. The media used was freshwater which was pumped and stored in a tendon bath, then aerated for one day prior used.

Table 1: Composition of experimental feed ingredients (g / 100g feed)

\begin{tabular}{|c|c|c|c|c|}
\hline Ingredients & \multicolumn{4}{|c|}{ Feed Type (\%) } \\
\hline & A & B & C & D \\
\hline Fish flour & 40.48 & 40.4800 & 40.480 & 40.4800 \\
\hline Soybean flour & 30.14 & 30.1400 & 30.140 & 30.1400 \\
\hline Fine bran & 17.38 & 17.3800 & 17.380 & 17.3800 \\
\hline Fish oil & 4.00 & 3.9995 & 3.999 & 3.9985 \\
\hline Vitamin mix & 2.00 & 2.0000 & 2.000 & 2.0000 \\
\hline Mineral mix & 3.50 & 3.5000 & 3.500 & 3.5000 \\
\hline $\mathrm{CMC}^{\mathrm{Cr}_{2} \mathrm{O}_{3}}$ & 2.00 & 2.0000 & 2.000 & 2.0000 \\
\hline Thyroxine hormone & 0.50 & 0.5000 & 0.500 & 0.5000 \\
\hline Total & - & 0.0005 & 0.001 & 0.0015 \\
\hline Contribution of protein & 100 & 100 & 100 & 100 \\
\hline
\end{tabular}

\section{Methods}

\subsection{Preparation}

Before the research was carried out, several preparations were made consisting of the preparation of tanks, feed, and prawns.
Tanks preparations were tanks sterilization, arrangement of position, aeration and thermostat water heater preparation. Feed preparations were preparation of feed formulations and feed making. Preparation of test prawns was adapting prawns to the environment. The day before adaptation, prawns were selected to obtain a relatively similar weight. Next preparation was adaptation of feed to be given during study. The feed given at the time of adaptation is feed without the addition of the thyroxine hormone. Adaptation to feed was carried out until the prawn gives a good response to the given feed (for a week). Prawns that have been accustomed to the feed given, fasted for one day, then weighed to find out the initial weight. During the study, the feed was given three times a day as much as $5 \%$ of the weight of prawn biomass. A sampling of weight and length measurements was done once a week. Then the siphon was carried out to determine the amount of feed that was not consumed. Feces were collected in bottles and stored in a freezer for chromium content to be tested for digestibility measurements.

The research method used was an experimental laboratory method - data obtained from observations and observations directly in the field.

\subsection{Experimental design}

The experimental design used was a completely randomized design using a different dose of thyroxine hormone as the treatment. Determination of this dose was based on research conducted by Handayani (2001) ${ }^{[7]}$ that the administration of thyroxine hormone into artificial feed at a dose of $10 \mathrm{mg} / \mathrm{kg}$ of feed can influence growth in weight and length. Data measured were specific growth rate (SGR), feed conversion value (FCR), protein efficiency ratio (PER), protein retention (RP), survival (SR) and feed digestibility.

\subsection{Data analysis}

The collected data were analyzed statistically to determine the effect of thyroxine administration on growth and survival of giant prawns. Diversity analysis or ANOVA F test was conducted to determine the best dosage according to the design used, which was a completely randomized design (CRD), while water quality data were analyzed descriptively (Nazir, 2003) ${ }^{[12]}$.

The data analyzed based on the design pattern used, and the data were tested for their normal variability with the Liliefors normality test, the data were tested for homogeneity of the variance by the population variance homogeneity test or the Bartleft test and additive test to reach the assumptions of the design pattern. If the treatment showed significantly different results, then preceded with the Duncan multiple region test to find out the differences between treatments.

\section{Results and Discussion}

\subsection{Results}

Table 2 shows data of SGR, Growth, FCR, SR, PER, and RP during study. The highest value of SGR was in treatment $\mathrm{C}$ $(0.770 \%$ / day $)$ with the addition of thyroxine hormone by 10 $\mathrm{mg} / \mathrm{kg}$ of feed, then followed by treatment $\mathrm{D}(0.762 \%$ / day $)$ with a dose of thyroxine hormone of $15 \mathrm{mg} / \mathrm{kg}$ of feed, B $(0.636 \%$ / day) with a dose of $5 \mathrm{mg} / \mathrm{kg}$ of feed and the lowest was treatment A $(0.484 \%$ / day) with a dose of $0 \mathrm{mg} / \mathrm{kg}$ of feed. The lowest SGR value was shown in treatment A. 
Table 2: Data of SGR, Absolute Biomass, Growth, FCR, SR, PER, and RP during study

\begin{tabular}{|c|c|c|c|c|}
\hline \multirow{2}{*}{ Parameters } & & & Treatments & \\
\cline { 2 - 5 } & A & B & C & D \\
\hline SGR - \%/day & $0.484 \pm 0.021$ & $0.636 \pm 0.020$ & $0.770 \pm 0.017$ & $0.762 \pm 0.02$ \\
\hline Absolute biomass growth (g) & $5.66 \pm 0.19^{\mathrm{a}}$ & $7.62 \pm 0.26^{\mathrm{b}}$ & $10.12 \pm 0.06^{\mathrm{c}}$ & $9.29 \pm 0.23^{\mathrm{d}}$ \\
\hline FCR & $3.584 \pm 0.238^{\mathrm{a}}$ & $2.437 \pm 0,149^{\mathrm{b}}$ & $2.110 \pm 0.091^{\mathrm{cb}}$ & $2.208 \pm 0.02^{\mathrm{b}}$ \\
\hline SR $(\%)$ & $75 \pm 0^{\mathrm{a}}$ & $78 \pm 3^{\mathrm{ab}}$ & $88 \pm 3^{\mathrm{c}}$ & $83 \pm 3^{\mathrm{b}}$ \\
\hline PER & $14.131 \pm 0.462$ & $19.036 \pm 0.637$ & $25.289 \pm 0.161$ & $23.208 \pm 0.562$ \\
\hline RP $(\%)$ & $10.535 \pm 0,527$ & $15.863 \pm 0,911$ & $23.062 \pm 0.682$ & $19.504 \pm 0.14$ \\
\hline
\end{tabular}

Numbers with different superscript letters indicate a significant difference $(P<0.05)$, while the same letters are not significantly different $(P>0.05)$ according to the Duncan region test.

Values of the FCR treatments of A, B, C, and D were 3.584, $2.437,2.110$ and 2.208 , respectively. Treatment $C$ had the lowest value, and the highest value was treatment $\mathrm{A}$. The lower the FCR value, the more efficient the feed was used by the prawns. The SR value of the giant prawns from each treatment was treatment A (75\%), B (78\%), C (88\%) and D $(83 \%)$. Treatment $\mathrm{A}$ had the lowest survival value, and treatment $\mathrm{C}$ had the highest survival.

The PER values of each treatment showed that treatment $\mathrm{C}$ gives the highest PER value of 25.289 compared to treatment D (23.208), B (19.036) and A (14.131). The retention protein value of test prawn from each treatment was A $(10.535 \%), \mathrm{B}$ (15.863\%), C (23.062\%) and D (19.504\%). The highest value of protein retention was obtained from treatment $\mathrm{C}$, and the lowest value was obtained from treatment $A$. Feed digestibility of each treatment can be seen in Table 3 .

Table 3: Digestion consists of total protein digestibility (TPD) and crude protein digestibility (CPD).

\begin{tabular}{|c|c|c|}
\hline Treatments & $\begin{array}{c}\text { Total protein } \\
\text { digestibility (TPD) (\%) }\end{array}$ & $\begin{array}{c}\text { Crude protein } \\
\text { digestibility (CPD) (\%) }\end{array}$ \\
\hline A & 83.96 & 75.1 \\
\hline B & 86.61 & 77.3 \\
\hline C & 93.23 & 86.9 \\
\hline D & 89.05 & 80.2 \\
\hline
\end{tabular}

From the table above, it can be concluded that the highest digestive value was obtained in treatment $\mathrm{C}$ of $86.9 \%$. Then sequentially followed by treatment $\mathrm{D}(80.2 \%)$, treatment B $(77.3 \%)$, and treatment A $(75.1 \%)$. In crude protein digestibility, the highest value was obtained in treatment $\mathrm{C}$ $(93.23 \%)$, then followed by treatment D (89.05\%), B $(86.61 \%)$ and treatment $\mathrm{A}(83.96 \%)$.

Water quality parameters during the study consisted of temperature, acidity $(\mathrm{pH})$, dissolved oxygen (DO), and ammonia $\left(\mathrm{NH}_{3}\right)$. Observation of water quality carried out for 35 days in an aquarium was presented in Table 4.

Table 4: Observation of water quality carried out for 35 days in an aquarium

\begin{tabular}{|c|c|c|c|}
\hline $\begin{array}{c}\text { Water quality } \\
\text { parameters }\end{array}$ & Values & Requirement & Reference \\
\hline Temperature $\left({ }^{\circ} \mathrm{C}\right)$ & $27-29$ & $25-30$ & Khairuman and Amri. $(2004)^{[8]}$ \\
\hline $\mathrm{pH}$ & $7,8-8$ & $7,75-8,21$ & Hadie and Supriatna $(1991)^{[6]}$ \\
\hline $\mathrm{DO}(\mathrm{mg} / \mathrm{L})$ & 5,8 & $5-7$ & Agriculture department $(1991)^{[1]}$ \\
\hline Ammonia $(\mathrm{mg} / \mathrm{L})$ & 0.04 & $<0,1$ & Rachmatun and Hardjono. $(1987)^{[14]}$ \\
\hline
\end{tabular}

\subsection{Discussion}

\subsubsection{Specific growth rate and absolute biomass growth}

The observation of the daily specific growth rate and absolute biomass growth from the 0th week to the 5th week explains that the addition of the thyroxine hormone affected absolute prawn biomass growth. The strongest influence was obtained in treatment $\mathrm{C}(10 \mathrm{mg} / \mathrm{kg}$ of feed) then followed by treatment $\mathrm{D}(15 \mathrm{mg} / \mathrm{kg}$ feed $)$, treatment B $(5 \mathrm{mg} / \mathrm{kg}$ feed $)$ and the lowest value obtained by treatment $\mathrm{A}(0 \mathrm{mg} / \mathrm{kg}$ of feed $)$.

The growth was supported by the results of FCR data (feed utilization efficiency). This data explains that starting from treatment $\mathrm{A}$ to treatment $\mathrm{C}$, the value of efficient utilization of feed was getting better. This means the thyroxine hormone affected the efficiency of feed utilization through metabolism and energy conversion (calorigenesis). As Buwono (2000) ${ }^{[3]}$ mentioned, in the process of protein, carbohydrates and fats are converted into energy. The protein with carbohydrates will be converted into pyruvic acid, then converted back to Acetyl CoA, where the fat is also directly converted into Acetyl CoA. The acetyl CoA then enters the tricarboxylic acid cycle, which is then converted into ATP which is used for growth and survival. Some acetyl CoAs that do not enter the tricarboxylic acid cycle will be stored as fat reserves.

The efficiency of feed utilization was influenced by the digestibility of prawn. The better the prawn can digest the feed given, the more efficient the feed can be utilized by the prawn to be converted into energy. According to Palinggi (1999) ${ }^{[13]}$, the digestibility level is the number of feed substances that can be absorbed in the digestion of the feed given. Prawn digestibility data explained that the effect of the thyroxine hormone on the efficiency of feed utilization indirectly affects the digestibility of prawn.

However, at a dose of $15 \mathrm{mg} / \mathrm{kg}$ of feed, this may decrease due to the excess dose given. As stated in Fujaya (2004) ${ }^{[5]}$ that thyroxine also has a biphasic effect, i.e. at low doses it is anabolic while at high doses catabolic.

\subsubsection{Survival rate level}

Survival is an opportunity to live in a certain moment. One of the factors that influence the high and low survival of prawn is the feed factor. The results of the above analysis indicate that the level of Survival rate has increased and has an effect on the hormone thyroxine added to the artificial feed. The thyroxine hormone indirectly affects the metabolism of proteins, carbohydrates, and fats which will then undergo conversion into energy for growth and survival. According to Afrianto and Liviawaty (2005) ${ }^{[2]}$, there is nothing more important in fish farming than the provision of artificial feed that is good at supporting nutritional needs and energy and maximizing the level of feed consumption. If there is no food consumed, the fish will not experience growth, even death. A good level of feed consumption will affect the efficiency of feed utilization. The influence provides the fulfillment of nutritional needs that will be converted into energy for growth and survival of prawn.

This survival rate level is also supported by measured water quality data; Water quality data shows a reasonable range of prawn life in metabolizing and sustaining life. The 
temperature for prawn is good at morning and evening measurements between $27-29^{\circ} \mathrm{C}$. The degree of acidity $(\mathrm{pH})$ for prawn ranges from $7.8-8$, where the number is still feasible for the maintenance of giant prawn and can inhibit the decomposition process of the ammonia and hydrogen sulfide toxicity. Dissolved oxygen results $(5.8 \mathrm{mg} / \mathrm{L})$ and ammonia $(0.04 \mathrm{mg} / \mathrm{L})$ are also in the proper range. Water with a low dissolved oxygen concentration can affect the health of prawn because prawn will be more susceptible to diseases and parasites. The quality of water is good, causing the body's metabolic processes to work well. Smooth metabolism can improve prawn appetite so that growth can run well and be able to maintain its survival.

\section{Conclusions and Suggestion \\ 5.1. Conclusion}

Based on the results of the study, it can be concluded that the addition of thyroxine hormone affects the growth and efficiency of the use of giant prawn.

\subsection{Suggestion}

Suggestions that can be given are more research is needed regarding the dosage used to obtain the optimal and best dose of thyroxine hormone for growth and the efficiency of the use of giant prawn feed using different culture sizes or by using different treatments.

\section{References}

1. Agriculture Department. Pembenihan Udang Galah (Macrobrachium rosenbergii de Man). Balai Informasi Pertanian Riau, Riau. Hlm 1991, 20.

2. Afrianto E, dan Liviawaty E. Pakan Ikan (Pembuatan, Penyimpanan, Pengujian, Pengembangan). Kanisius, Yogyakarta 2005, 148.

3. Buwono Ibnu D. Kebutuhan Asam Amino Essensial dalam Ransum Ikan. Kanisius, Yogyakarta 2000, 56 Hlm.

4. De Grave S. Macrobrachium lepidactylus. The IUCN Red List of Threatened Species 2013.

5. Fujaya Y. Fisiologi Ikan (Dasar Pengembangan Teknologi Perikanan). Rineka Cipta, Jakarta 2004.

6. Hadie W, dan Supriatna J. Pengembangan Udang Galah dalam Hatchery dan Budidaya. Kanisius, Yogyakarta. Hlm 1991, 11-39.

7. Handayani S. Dosis optimum $3,5,3^{\prime}$ - - triiodotironin $\left(\mathrm{T}_{3}\right)$ dalam Pakan Untuk Pertumbuhan Ikan Gurami (Osphronemus gouramy, Lac.). Tesis. Program Pascasarjana. IPB, Bogor 2001.

8. Khairuman SP, dan Amri Khairul. Budidaya Udang Galah Secara Intensif. Agromedia Pustaka. Jakarta. Hlm 2004, 10-20.

9. Little AG, Frank S. The evolution of endothermy is explained by thyroid hormone-mediated responses to cold in early vertebrates. Journal of Experimental Biology 2014;217:1642-1648.

10. Matty AJ. Fish Endocrinology. Croom Helm, London, and Sidney Timber 1985, 267pp.

11. Murtidjo BA. Budidaya Udang Galah Sistem Monokultur. Cetakan Pertama. Kanisius, Yogyakarta 1992.

12. Nazir M. Metode Penelitian. Ghalia Indonesia, Jakarta. Hlm 2003, 346-468.

13. Palinggi NN. Potensi Bahan Baku Pakan di Sulawesi Selatan. Balai Penelitian Perikanan Pantai. Maros 1991, $234 \mathrm{hlm}$.
14. Rachmatun S, dan Hardjono. Balai Pembenihan Udang: Desain Pengoperasian dan Pengelolaannya. Direktur Jendral Perikanan, Jakarta. Hlm 1987, 72-75. 